\title{
Autolytic Enzymes in Fungal Cell Walls
}

\author{
R. MITCHELL* AND NAAMA SABAR \\ Weizmann Institute of Science, Biochemistry Section, Rehovoth, Israel
}

(Received 25 June 1965)

\begin{abstract}
SUMMARY
Autolytic glucanase and protease activity was detected in cell walls of some pythium species prepared by ultrasonic treatment. The glucanase activity was correlated with mycelial development. Maximal glucose release was detected in growing cultures during the linear growth period of the fungus. Assays of glucanase activity in cell walls prepared from mycelium harvested at different times showed that the enzymic activity increased with the age of mycelium from which the cell walls were prepared. The relationship between autolytic enzymes and mycelial development is discussed.
\end{abstract}

\section{INTRODUCTION}

Enzymic lysis of fungal cell walls by other micro-organisms has been reported for a number of fungi. Horikoshi \& Iida (1958) associated lysis of aspergillus by some bacillus species with the action of a chitinase. Mitchell \& Alexander (1963) showed the activity of a chitinase and protease in bacterial degradation of Fusarium cell walls. With these fungi the source of the lytic enzymes was another micro-organism. Bacterial lysis of pythium has been investigated in our laboratory (Mitchell \& Hurwitz, 1965). During these investigations preparations were made of fungal cell walls and evidence was obtained which suggested that autolytic enzymes were active in the cell-wall preparations (Mitchell \& Sabar, 1966). This report will describe the action of autolytic enzymes on Pythium cell walls.

\section{METHODS}

Cultures of Pythium butleri and Pythium myriotylum for cell-wall preparation were incubated at $30^{\circ}$ for 3 days. The medium used was a potato glucose liquid medium (Mitchell \& Hurwitz, 1965). For measurements of glucose release from actively developing cultures of pythium corn meal was substituted for glucose. Cell walls were prepared by ultrasonic treatment of $20 \mathrm{ml}$. batches with a Branson 'Sonifier' ultrasonic oscillator in an ice bath for $3 \mathrm{~min}$. The walls were washed six times until free from cytoplasmic material by centrifugation in a refrigerated centrifuge at $5000 \mathrm{~g}$ for $10 \mathrm{~min}$; the cytoplasmic material remained in suspension. Walls were washed with 0.05 M-potassium phosphate buffer ( $\mathrm{pH} 7$ ), until shown to be free from cytoplasmic material by phase-contrast microscopy, and by examining the extinction at $260 \mathrm{~m} \mu$ in a Zeiss spectrophotometer.

* Present address: Laboratory of Applied Biology, Division of Engineering and Applied Physics, Harvard University, Cambridge, Mass., U.S.A. 
Glucanase activity was measured by determination of glucose release by the glucose oxidase method (Keston, 1956; the reagent was obtained from Worthington Biochemical Corp. Freehold, N.J.). Proteolysis was determined by the method of Moore \& Stein (1954).

Double-layer plates were used to assay for the presence of bacteriophage from culture filtrates during cell-wall autolysis. The bottom layer consisted of potato glucose agar (Difco). A mixture of autolytic filtrate and an inoculum of pythium mycelium was added to $0.6 \%$ agar at $45^{\circ}$; this medium was then spread on the surface of the solidified bottom layer. Petri dishes were incubated at $30^{\circ}$. Ultracentrifuge analyses were done with a Spinco ultracentrifuge. Samples were suspended in $0.5 \mathrm{M}$ potassium phosphate buffer $(\mathrm{pH} 7)$. All samples analysed in the ultracentrifuge had extinction readings greater than 1.0 when measured in a Zeiss ultraviolet spectrophotometer at $260 \mathrm{~m} \mu$.

\section{RESULTS}

During studies of the chemical structure of pythium cell walls (Mitchell \& Sabar, 1966) it was observed that large quantities of glucose were released in control tubes containing cell walls alone during incubation at $37^{\circ}$. These observations suggested a tendency of the mycelium of this fungus to undergo autolysis. To study this phenomenon in greater detail cell walls of Pythium butleri and P. myriotylum were prepared, precautions being taken to prevent destruction of enzymes which might be present in the cell-wall material. These two pythium species have been shown to contain a glucan as the only polysaccharide. $P$. butleri glucan was found to be $\beta 12$ linked, whereas the linkage of $\boldsymbol{P}$. myriotylum was $\beta$ 14 (Mitchell \& Sabar, 1966).

Autolytic activity was determined by measuring release of glucose and amino groups. Both species tested showed strong glucanase activity against their own glucans, as shown by the rapid release of glucose. Proteolysis was also detected in cell-wall preparations of both species of the fungus. There was little difference in the rate of release of amino groups between the two species. Both autolytic glucans and protease activity were inhibited by heating the cell-wall preparations at $90^{\circ}$ for $30 \mathrm{~min}$.

Tests were made to determine whether autolytic activity was related to phage infection of the fungus. Double-layer plates were prepared and inoculated with growing mycelium together with culture filtrate from actively growing mycelium. No plaques were observed. Culture filtrates were tested for the presence of nucleotide material by measurement of extinction in the u.v. spectrophotometer. No significant peak was found at $260 \mathrm{~m} \mu$, indicating the absence of nucleotide material. Neither ultracentrifugal nor electron microscope analyses yielded evidence of phage particles.

The relationship between autolytic activity and mycelial growth was examined. To determine the rate of growth of pythium mycelium, Erlenmeyer flasks were inoculated with the Pythium butleri and incubated at $\mathbf{2 5}^{\circ}$. The growth rate was determined by measurement of the weight of dried mycelium harvested at various times. The mean of weights obtained from three flasks was used at each sampling time. These data showed a linear rate of growth for 10 days; between 10 and 14 days the dry weight did not increase. 
Measurements of quantities of glucose released into the medium during growth of Pythium butleri in liquid culture showed a linear rate of release during the period of most active growth of the fungus. A potato corn meal medium was used. Typical data for $P$. butleri are shown in Fig. 1 . The glucose concentration in the medium reached a maximum after 6 days of incubation and then began to decline.

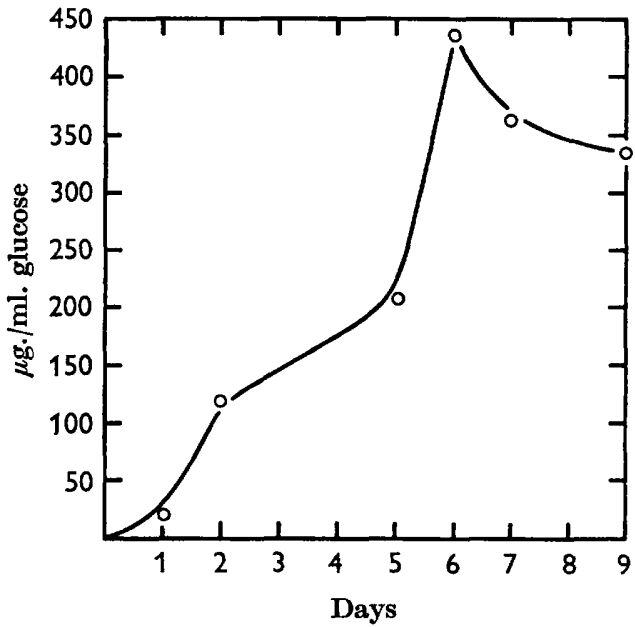

Fig. 1

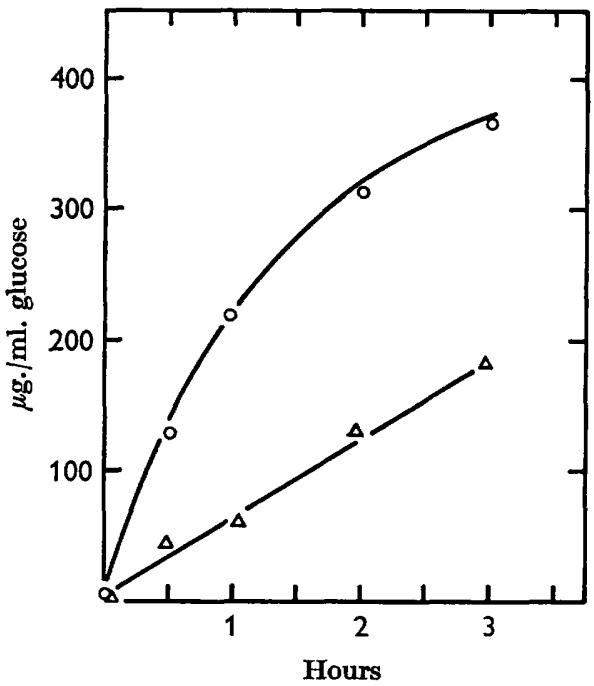

Fig. 2

Fig. 1. Relationship between the age of the Pythium culture from which cell walls were prepared and autolytic glucanase activity.

Fig. 2. Relationship between mycelial growth of Pythium and release of glucose into the medium by whole mycelium. $\triangle$, 3-day culture; $O$, 7-day culture.

Cell walls were prepared from Pythium butleri mycelium harvested at different incubation times, to test the relationship between mycelial age and autolytic glucanase activity of the cell walls. Some of the data obtained are shown in Fig. 2. The cell walls prepared from 7-day mycelium yielded glucose $120 \mu \mathrm{g}$. / $\mathrm{ml}$. cell-wall preparation $/ \mathrm{hr}$. as compared to $60 \mu \mathrm{g}$. $/ \mathrm{ml}$. by cell walls from 3-day cultures. Walls prepared from $24 \mathrm{hr}$ cultures displayed autolytic activity but values were not higher than glucose $15 \mu \mathrm{g} . / \mathrm{ml}$. culture released $/ \mathrm{hr}$.

\section{DISCUSSION}

Weidel, Frank \& Leutgeb (1963) reported autolysis of salmonella cell-walls and pointed out that precautions should be taken against autolysis in the study of bacterial cell walls. Results obtained in the current investigation show that similar care must be taken in the study of fungal cell-walls. Both cell-wall glucan and protein of Pythium were susceptible to degradation by autolytic enzymes. Young, Spizizen \& Crauford (1963) showed autolytic activity in Bacillus subtilis cell walls, and associated autolysis with competence for transformation. Genetic transfer in fungi occurs either by parasexuality or by karyogamy. These sexual processes are rare in the Phycomycetes (Raper, 1955); sexual forms were not observed in the cultures used in the present work. Cell-wall lysis has also been observed during release of 
bacterial spores (Greenberg \& Halvorson, 1955). The small numbers of spores observed in our pythium cultures excluded this possibility. Park (1956) observed that klebsiella cell walls were lysed by enzymes carried by the phage during bacteriophage infection. No evidence of phage infection of pythium was detected here.

Cell-wall autolysis of Staphylococcus aureus has been shown to occur during cell division (Mitchell \& Moyle, 1954). It has been suggested (Strange, 1959) that these autolytic enzymes may either have a synthetic function or be related to the change in state of the dividing bacteria. Our results show a direct relationship between fungal growth and autolytic activity. The strong activity observed in cell walls prepared from old pythium mycelium may be a result of the combined activity of autolytic enzymes associated with growth and senescence. The rapid rate of branching which occurs during development of young hyphae of pythium suggests that branching points may be sites of maximum lytic activity. However, both mycelial growing tips and cell-wall synthesis may equally account for the relationship between autolysis and growth.

\section{REFERENCES}

Greenberg, R. A. \& Halvorson, O. H. (1955). Studies on an autolytic substance produced by an aerobic sporeforming bacterium. J. Bact. 69, 45.

Horikoshi, K. \& IIDA, S. (1958). Lysis of fungal mycelia by bacterial enzymes. Nature, Lond. 181, 917.

Keston, A. S. (1956). Specific colorimetric reagents for glucose. Abstr. 129th Meeting, Am. Chem. Soc. p. 31 c.

Mitcheld, P. \& MoYLe, J. (1957). Autolytic release and osmotic properties of protoplasts from Staphylococcus aureus. J. gen. Microbiol. 16, 184.

Mrtchell, R. \& Alexander, M. (1963). Lysis of soil fungi by bacteria. Can. J. Microbiol. $9,169$.

Mrtchell, R. \& HuRwrtz, E. (1965). Suppression of Pythium debaryanum by lytic rhizosphere bacteria. Phytopathology, 55, 156.

Mrtchell, R. \& Sabar, N. (1966). Hyphal cell wall structure of two species of Pythium. Can. J. Microbiol. (in the Press).

Moore, S. \& SteIN, W. H. (1954). A modified ninhydrin reagent for the photometric determination of amino acids and related compounds. J. biol. Chem. 211, 907.

PARK, B. H. (1956). An enzyme produced by a phage-host-cell system. I. The properties of a Klebsiella phage. Virology, 2, 711.

RAPER, J. R. (1955). Heterokaryosis and sexuality in fungi. Trans. N. Y. Acad. Sci. Ser. II, 17, 627 .

Strange, R. E. (1959). Cell wall lysis and the release of peptides in Bacillus species. Bact. Rev. 23, 1.

Weidel, W., Frank, H. \& Leutgeb, W. (1963). Autolytic enzymes as a source of error in the preparation and study of Gram-negative cell walls. J. gen. Microbiol. 30, 127.

Young, F. E., Spizizen, J. \& Crauford, I. P. (1963). Biochemical aspects of competence in the Bacillus subtilis transformation system. I. Chemical composition of cell walls. J. biol. Chem., 238, 311. 